\title{
Research and Practice of Curriculum of Network Engineering in Application-oriented Undergraduate Teaching
}

\author{
LI Yong-fei ${ }^{\mathrm{a}}$, ZHAO Qiao-fang $^{\mathrm{b}}$ \\ ${ }^{a}$ Department of Computer, North China Institute of Science and Technology, Beijing, China \\ ${ }^{b}$ Department of Electrical and Mechanical Engineering, North China Institute of Science and Technology, \\ Beijing, China
}

\begin{abstract}
Network engineering was a new discipline for undergraduate in china. There were some imperfections in the curriculum of network engineering in application-oriented undergraduate teaching. Based on the analysis of training goals of network engineering in application-oriented undergraduate teaching, three professional directions were brought forward. Professional direction training was integrated from the teaching content in the forth year. Professional skills and vocational quality were the same important in the curriculum.
\end{abstract}

Index Terms: Network engineering; curriculum; application-oriented undergraduate teaching; courses integration

(C) 2011 Published by MECS Publisher. Selection and/or peer review under responsibility of the International Conference on E-Business System and Education Technology

\section{Introduction}

With the rapid development and wide usage of computer network technology, the demand of network technicians substantially increased in society. Network engineering was a new discipline for undergraduate in china. The training goal, curriculum, teaching and evaluation method of network engineering were not yet complete. At the same time, there were considerable differences between various colleges and universities. Therefore, it was necessary to research the teaching issues of network engineering. With the application orientation of North China Institute of Science and Technology, the curriculum of network engineering was analyzed and researched.

In [1], Liu Daoyu pointed out that the curriculum was an entirety which consisted of many interrelated courses, not just a set of isolated courses. The curriculum was very important in the teaching system, and directly related to what kind of talent would be cultivated. And in [2], Yang Shuzi believed that the course system, curriculum, course content and teaching methods reform were difficulties of teaching reform, which was the core of

\footnotetext{
* Corresponding author.

E-mail address: ${ }^{\mathrm{a}}$ lyf518@ @ ncist.edu.cn, ${ }^{\mathrm{b}}$ zhaoqiaofang@ @ ncist.edu.cn
} 
undergraduate teaching nowadays. It could be said that curriculum was one of the key factors of quality of higher education.

Curriculum was the focus of achieving the training goal. The courses in a curriculum should be arranged according to teaching rule, coherent naturally, with paying attention to training of cultural quality, innovation and vocational skills.

\section{Training goal of network engineering}

The Ministry of Education of the People's Republic of China proposed that universities and colleges should dilute the professional awareness, broaden the base and strengthen quality education and capacity-building. Moreover, current graduates would choose various kinds of vocations and change their job frequently. Such situation resulted in that the old training mode that lead narrow base and poor adaptability should be reformed. The training goal of undergraduate teaching should be deep foundation, wide caliber, and high-quality.

However, as a new college, North China Institute of Science and Technology was application-oriented because of its current teaching conditions and the specific needs of graduates. The graduates of applicationoriented undergraduate teaching were professional that engage in high-tech in industry [3]. So, they should be application-oriented undergraduates with solid theoretical basis and strong practice capacity. Thus they could be accepted by the employers and improve their career better and better.

The training goal set for the network engineering was: senior application-oriented graduates with innovative spirit and practical ability, with basic training in computer network engineers, with the ability of comprehensive planning and implementation of computer network, management and maintenance of computer network, and design and development of computer network software, with comprehensive development of physical and moral.

The curriculum should be designed based on training goal, and serve training application-oriented undergraduates.

\section{The design principles of the Application-oriented Curriculum}

There were some principles that should be followed when design the curriculum to reflect the applicationoriented training goal.

\section{A. The foundation theory should be choose moderately according to the training goal}

In [3], Xu Liqun believed that the training of application-oriented undergraduates should emphasize forindustry, and the structure of subject knowledge should be constructed according to the requirements of industry. It was different from academic-oriented undergraduates that require integrity and systemic of knowledge structure. Therefore, the courses of foundation theory should be selected according to the training goal and server the application-oriented teaching. At the same time, there should be considerable applied professional courses to train proficiency. We agreed with his viewpoint.

\section{B. Professional directions should be set clearly according to the actual needs of the industry}

As the training goal of application-oriented college was senior application-oriented graduates, the knowledge structure of the graduates should be designed for practical requirements, and capacity system focus on practical requirements [4]. Similarly, the curriculum should also be set for practical requirements in industry. The division of work in network industry became clearer and clearer with the development of network technology and expansion of networking application filed. It was impossible and unnecessary to ask all students to learn network skills about all directions and to adapt to all the positions in network industry.

Therefore, different professional direction should be set in senior undergraduate. And also career planning should be provided to guide students to choose right professional direction according to their own conditions and interests. The students could focus on really useful knowledge, acquire practical skills and be competitive in job searching. 


\section{Teaching content should be integrated for the practice ability}

As an engineering professional, the comprehensive proficiency must be achieved through the practice teaching phases. In application-oriented college, not only the cultivation of professional skills was important for highquality graduates, but also the vocational quality training. As a prevalent dilemma in current job market, students could not find satisfied job and enterprise could not recruit qualified personnel. That reflected that there were dislocations between the professional skills which the students had and what the employers needed. Moreover, the graduates who had worked for one year with some working experience would be greatly competitive for employment. That meant that a necessary transition was absent between the professional education in college and career needs of employer.

After the professional directions are set clearly, the practical teaching contents scattered in different practice teaching courses should be integrated for professional capacity building. And vocational quality education should be introduced into the practical teaching phases. Thus the students could acquire not only good professional skills but also appropriate vocational capacity, and be more competitive in job market.

\section{Curriculum of Network Engineering}

The principles mentioned above were implemented in the design of curriculum of application-oriented network engineering. The choice of foundation theory courses were treated in another paper. Professional training and practice courses integration were discussed here.

\section{Setting professional directions}

After research and analysis of requirements of network professionals, three professional directions were set up according to its features: network planning and implementation, network management and security, network application development. The three directions covered network construction, management and application, were interrelated closely, and reflects the employment category of network professionals.

Network planning and implementation was the basic platform of other network applications. The following tasks were included: to choose a variety of hardware and software products based on the user's requirements and funding, to design and install the products with computer and network technology, and to make the integrated system to meet the user's actual work requirements and be good at cost-effective [5].

Network management and security referred to the management and maintenance of network. The following tasks were included: to analyze network performance and potential failure to enable more efficient network operation and more efficient use of network resources, to protect security of network systems and critical data. Essential knowledge for network management and security were network theory, a variety of network security technology, common network management software and network security systems.

Network application development referred to development and maintenance of network application. The following tasks were included: to design developing plan of network application according to user's actual situation and specific need, to implement the program with a certain development tool to meet the user's need in specific application areas.

\section{E. Integrating Training Curriculum}

Training was the key interface between college education and vocational needs. In the traditional teaching plan, there had been various kind of practical teaching content, including experimental class and comprehensive experiments in professional courses, professional course related projects exercises, as well as internship and so on. There were two shortcomings in the old plan. Firstly, such teaching units were set up independently and lack of intrinsic link. Secondly, only professional skills were focused but not vocational quality. In fact, it was impossible to cultivate vocational quality in the old practical teaching.

The forth year was treated as a whole training phase and designed different content for the three professional directions. Just mentioned above, there were many practical contents including experimental class and comprehensive experiments in professional courses, professional course related projects exercises, and internship in the old curriculum. They were integrated with breaking the boundaries between different teaching contents [6]. 
Students could choose one of the three directions as his/her main direction, and acquired the training of the direction.

The training phase was organized in the form of project development. There was a specialize course for each professional direction (such as network engineering corresponding to the network planning and implementation, network security to management and security, and web application development to network application development). And there were also a group of related optional courses as supplement. Meanwhile, the cultivation of vocational quality was introduced into the training content for students to obtain the required professional skills and vocational quality.

The first half of the training phase (the formerly seventh semester) focused on professional skills training. The original teaching forms were still used, such as experimental class, project exercise and internship. But the teaching content should be consistent for a professional direction, and be organized for the development of a specific project. The latter half of training phase (formerly the eighth semester) was the development of the project where the students were grouped into teams. It is better to adopt the teaching forms like simulated work environment or business internships to help student early entry to the occupational status. Students could obtain professional skills and vocational quality useful when searching job during such training phase.

\section{F. Curriculum system of network engineering}

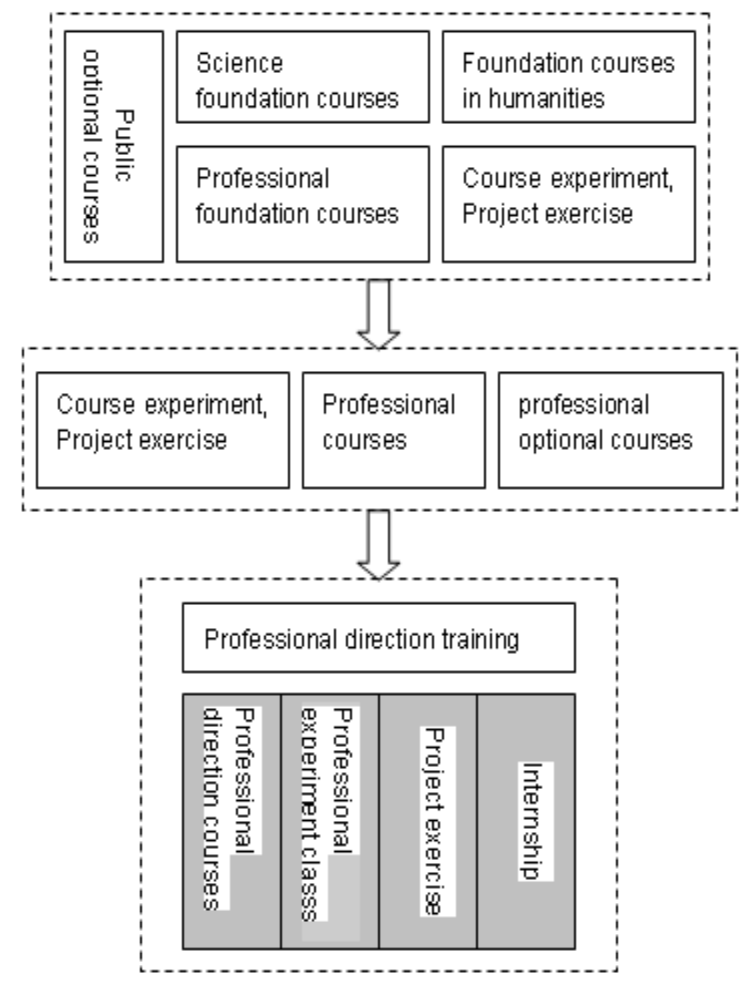

Figure 1. Curriculum system of network engineering.

The overall four-year teaching scheme was divided into three sections, 2 years for foundation course, 1 year for professional courses and 1 year for professional direction training. The curriculum system was shown in Fig. 1.

- Foundation courses include: foundation courses in humanities, science foundation courses, professional foundation courses, public optional courses and related practice teaching (including course experiment and project exercise). 
- Professional Courses included: professional courses, professional optional courses and related practice teaching (including course experiment and project exercise).

- Professional direction training was the integration of original teaching contents in the forth year, including professional direction courses, professional experiment class, project exercise and internship (the contents with gray background in the fig. 1).

\section{Conditions for the implementation of the curriculum}

The curriculum designed above was quite different from the traditional academic undergraduate curriculum. In the implementing process, the following conditions should be provided to ensure its effectiveness.

\section{G. Strengthening guidance of professional directions}

Here the professional direction was in fact the initial career planning of students. Special teaching content should be set up to remind students to determine their professional direction as soon as possible. Then they could choose appropriate professional optional courses according to their decision. It would be best to hold a seminar about professional direction and career planning in each semester.

\section{H. Emphasizing optional courses}

In the curriculum, optional courses were very important to distinguish the various professional directions. There was a wrong opinion that optional courses were non-essential. The position of optional courses should be improved through teaching management system reform. The real role of optional courses was to provide choice for students in professional directions.

\section{Promoting the research on teaching reform}

The new curriculum was comprehensive integration of teaching content. The professional courses and professional direction courses should be arranged appropriate for three professional directions. In particular, the professional direction training in the fourth year was longer and made up of many teaching content. It was necessary to study the teaching methods, evaluation methods and other aspects of new curriculum.

\section{J. Updating teaching content timely}

After the curriculum was established, the specific teaching content must be adjusted in time based on the practical needs of the employer. Especially the teaching content and teaching method of professional direction training must be revised according to employment needs and current shortage of jobs at any time. It could provide maximum help in employment for students to ensure that the professional skills and vocational quality students learned were indeed critical for the employer.

\section{K. Enhancing college-enterprise cooperation}

The contents of professional training and its effective implementation required cooperation between colleges and enterprises. On one hand, employment needs and current shortage of jobs must be gained from the enterprise as target of training. And on the other hand, the internship positions provided by enterprises were in fact induction. That made seamless connection between college and enterprise for students.

\section{Summary}

Three professional directions of network engineering were proposed through the analysis of curriculum design principles and study of professional training goal. The teaching contents in the fourth year were rearranged to professional direction training by breaking the boundaries between the different teaching items. The cultivation of practical capacity was emphasized here. The ideas of the new curriculum might have some reference value for other application-oriented undergraduate teaching. The new curriculum also required appropriate conditions. The best result could be achieved only with overall reform on teaching content and teaching method. 


\section{References}

[1] LIU Daoyu, "On the reform of the Undergraduate Curriculum" Higher Education Exploration(in Chinese). Jan. 2009, pp:5-9

[2] YANG Shuzi, ZHANG Furun, WU Changlin "Acquire knowledge beyond the knowledge and improve quality of education" China Higher Education Research(in Chinese). Feb. 2005, pp:5-10

[3] XU Liqun, GU Jianmin, "Discussion of Mode of Talent Cultivation and operation conditions in Applied Undergraduate teaching" Higher Education Exploration(in Chinese). Feb. 2007, pp:57-60

[4] XIA Jianguo, LIU Wenhua, "Analysis on the Mode of Talent Cultivation in 4-year Technological Undergraduate Colleges" Education and Vocation(in Chinese). Jul. 2006, pp:106-107

[5] TIAN Liqin, ZHANG Qiaohong, LI Yongfei, Tutorial of network Engineering Technology(in Chinese). China University of Mining and Technology Press, 2007

[6] LI Yongfei, DU Xingjing, "Discussion of Course Teaching Scheme in Java Web Programming" China Electric Power Education(in Chinese). Jun. 2009, pp:106-107 